\title{
Religious Barriers to the Diffusion of Same-sex Civil Unions in Italy
}

\section{Gabriele Ruiu $^{1}$ (D) Giovanna Gonano ${ }^{1}$}

Received: 24 January 2019 / Accepted: 5 September 2020 / Published online: 23 September 2020

(C) The Author(s) 2020

\begin{abstract}
The legal recognition of civil unions between same-sex partners, in May 2016, could be defined as a revolution for the system of legal norms regarding the "heterosexual family-centric-system" in Italy. Using official data on the 17,341 people resulting in a same-sex civil union collected by the Italian National Institute of Statistics in the years 2016-2018, this paper analysed the relationship between religious secularization and the diffusion of same-sex civil unions at the regional level in Italy. In particular, an indicator of the incidence of civilly united individuals over total population has been regressed on the rate of heterosexual marriages celebrated according to the civil rite. According to abundant literature, the latter variable could be interpreted as a proxy of secularization. The results indicate that less secularized regions are also those where less civil unions have been celebrated. The results are confirmed also when an instrumental variable approach is implemented. Studying this topic in Italy is particularly interesting since the country has been defined as the least secularized among economically developed nations.
\end{abstract}

Keywords Same-sex civil union · Religious beliefs · Family · Catholicism · Secularization

\section{Introduction}

The position of the Catholic Church on same-sex relations is clearly stated in its Catechism: “...[T]hey are contrary to the natural law. They close the sexual act to the gift of life. They do not proceed from a genuine affective and sexual complementarity. Under no circumstances can they be approved...[T]his inclination, which is objectively disordered, constitutes for most of them a trial. They must be accepted with respect, compassion and sensitivity. Every sign of unjust discrimination in their regard should be avoided...[H]omosexual persons are called

Gabriele Ruiu

gabrieleruiu@gmail.com

1 Department of Economics and Business, University of Sassari, Via Muroni, 25, Sassari, Italy 
to chastity. By the virtues of self-mastery that teach them inner freedom, at times by the support of disinterested friendship, by prayer and sacramental grace, they can and should gradually and resolutely approach Christian perfection" (Catholic Catechism, 2357-2359).

According to Catholic doctrine, gay and lesbian individuals are considered to be people suffering from a "disorder". Although their sexual behaviour could not in any way be approved, they must be not discriminated against by other Catholics. The only way to behave in accordance with Christian precepts for this minority is to have chaste and disinterested friendships with members of the same sex. See Zaccaria (2015) for a more detailed discussion of the stances of the Catholic Church on samesex relationship.

Considering the data coming from the European Value Survey (the latest available for Italy), the Catholic position on Lesbian, Gay, Bisexual and Transgender (LGBT) people seems to be widely shared among Italians. Indeed, when the percentage of individuals declaring that they agree or strongly agree that same-sex couples should have the right to adopt children is considered, it turns out that in Southern Europe, only another Catholic Country (Malta) has a lower acceptance of adoption for same-sex couples than Italy (see Table 1, column 1). Note also that Orthodox Countries (Greece and Cyprus) are characterized by the most rigid position about the rights of LGBT people.

However, if the percentage of individuals declaring that they would not like to have LGBT people in the neighbourhood is considered instead, Italy is in line with other Catholic countries, including Austria, Ireland, Poland and Malta. Similar results have been obtained for the degree of acceptance of LGBT people as political leaders (this is derived from the 2012 Eurobarometer Survey). In particular, the latter variable was obtained from a survey question which asked respondents to assess, using a scale from 1 to 10 , how they would feel if a person belonging to this sexual minority were elected to the highest political position in the country. In the proposed scale, 1 means "totally uncomfortable" and 10 means "totally comfortable".

Note that in Table 1 for the dominant religion, this refers to the religion with the most adherents in the country according to the statistics reported by the Pew Research Centre. Accordingly, it seems that Catholic countries tend to have views that are between the very high level of acceptance of sexual minorities recorded in Northern Europe/Scandinavian countries and the very low level registered in Eastern Europe countries (see also the results of the study carried out by the Pew Research Center in 2013). However, most Italians are reluctant to give sexual minority people the same rights as heterosexual families, since only the latter are recognized by the religious authorities.

A survey carried out in 2011 by the Italian National Institute of Statistics (ISTAT) on a representative sample of the Italian Population aged between 18 and 74 years revealed that the $61.3 \%$ of the respondents believed that gay men and lesbian women were discriminated in the country (according to the 2012 Eurobarometer the same percentage for the whole European Union is equal to $46 \%$ ). In addition, a considerable share of the respondents $(29.7 \%)$ declared that for LGBT people is 


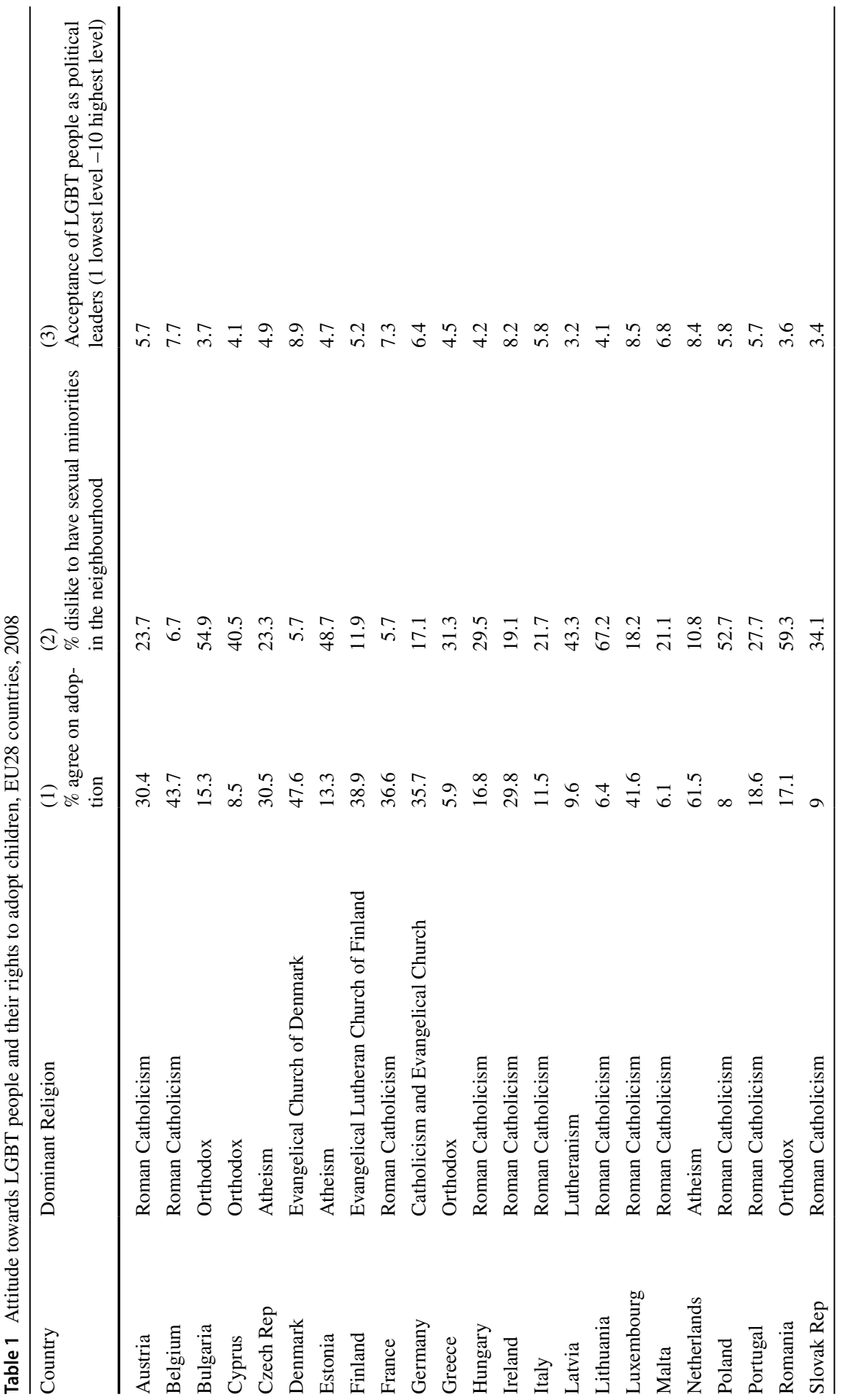




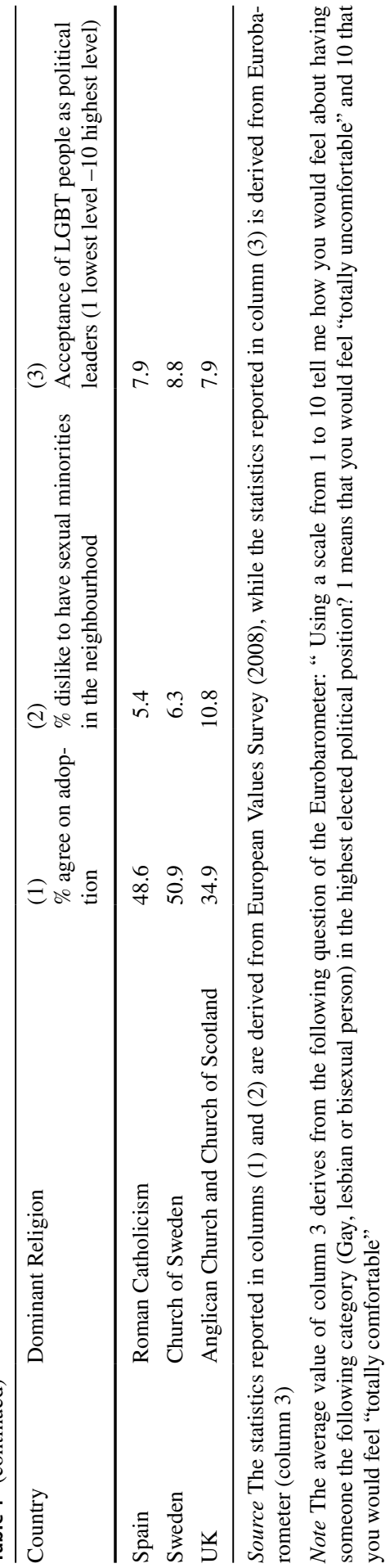


recommendable to not reveal their sexual identity to other people. At the same time, the $56.1 \%$ of the sample was moderately or strongly opposed to same-sex marriage. ${ }^{1}$.

Despite abundant literature investigating the link between religiosity and sexual identity (see for instance Worthington 2004; Bertone and Franchi 2014; Page et al. 2013; Walther et al. 2011), religiosity and attitude towards LGBT people (among others Zmyj and Huber-Bach 2019; Jäckle and Welzelburger 2015; Piumatti 2017; Janssen and Schepeers 2018) and between religion and attitude towards same-sex marriages (Bengtsson 2019 for Sweden; Sherkat et al. 2011, Gay et al. 2015 and Perry 2015 for the US; Ellison et al. 2011 for the community of the U.S. Latinos; Pecheny et al. 2011 for Argentina; Jennings 2011 for Spain), studying same-sex partnerships in Italy is particularly interesting, since the country has been characterized as a Catholic religious monopoly and as the least secularized among economically developed nations (see Breschi et al. 2018 for a brief discussion).

In addition, this research may also be relevant for other ambits in social science. For instance, a better understanding of the relationship between religiosity and sexuality may be useful in explaining why LGBT people seem to be less satisfied in life in comparison to heterosexual people (Powdthavee and Wooden 2014; Boertien and Vignoli 2019). Indeed, it may be argued that in addition to fuelling social stigma, intense religious beliefs could increase the difficulty experienced by individuals in accepting their own sexual identity and this in turn may produce negative effects in terms of the life satisfaction of LGBT people (see also Berggren et al. 2017; Baiocco et al. 2015; Anderton et al. 2011).

To the best of the authors' knowledge, the literature dealing with the Italian case has mainly focused on the legal aspects of the new law (Cipriani 2017; Saporiti 2017), on the political debate that led to its approval (Ozzano 2015; Schmitt et al. 2013; Lasio and Serri 2017), on the psychological barriers to becoming parents for LGBT people (Scandurra et al. 2019), and on the relationship between post-materialism and diffusion of same-sex civil unions (Pagliacci 2019), but there is a lack of work investigating the relation between secularization and the diffusion of civil unions.

The aim of the current study is to fill this gap by testing whether the Northern Italian regions, which are more secular, are also those where more same-sex couples have decided to officially celebrate their unions. It seems reasonable to assume that the percentage of gay men and lesbian women should be more or less equal across all Italian regions. Despite this, there are notable differences in terms of secularization (Breschi and Ruiu 2016). The position of the Catholic Church on same-sex marriage could therefore discourage — through social pressure-the officialization of civil unions, especially in less secularized Southern Italy. In particular, studying the parental reaction to the disclosure of 164 Italian gay and lesbian young adults, Baiocco et al. (2015) showed that negative reactions are significantly related to the

\footnotetext{
1 Details on the ISTAT's survey can be found at https://www.istat.it/it/archivio/62168, while the results of the Eurobarometer can be downloaded at https://data.europa.eu/euodp/en/data/dataset/S1043_77_4_ EBS393
} 
right-wing political conservatism of the parents and strong religious beliefs. ${ }^{2}$ Simi- $^{2}$ larly, Lingiardi et al. (2016) using a larger sample (about 700 individuals from Italy) reported that religious individuals tend to have more negative attitudes towards gay men and lesbian women. Another survey carried out by Rollè et al. (2018) among 223 Italians confirmed that those who define themselves as religious have more negative attitudes towards same-sex partnership and same-sex parenting.

Hence, the research question that this paper poses may be formulated as follows:

Could the different degree of secularization across the Italian Peninsula explain the regional heterogeneity in the diffusion of same-sex civil unions?

In order to answer this question, a linear regression model has been estimated where the dependent variable is a regional indicator of the incidence of civilly united individuals over total population in 2019, while the percentage of marriages celebrated with the civil rite is used as an indicator of secularization. All these data are derived from official Italian statistics. The use of civil marriages as indicator of secularization for Italy is not new in empirical literature (see for instance, Impicciatore and Billari 2012; Vignoli and Salvini 2014; De La Croix et al. 2019) since this type of marriage is not recognized by Catholic Church. Therefore, a marriage celebrated only with the civil rite is considered as never happened by religious authorities. Hence, this suggests that the lower the level of secularization, the lower the percentage of civil marriages.

Obviously, the results of simple linear regression model are often biased because of problem of omitted variables and/or of reverse causality. For this reason, the analysis is corroborated also by implementing the Instrumental Variable approach. In particular, the regional divorce rate in 1980 and the regional share of votes going to the Italian Communist Party in the 1979 elections are used as instruments for the civil marriage rate. As will be further clarified in the methodological section, the choice of the divorce rate has been driven by the literature on the "Second Demographic Transition" (Lesthaeghe 2014), while the use of the votes to the Communist Party derives from the very tense relationship between this Party and Roman Catholic Church in the considered period.

\section{The Difficult Path of the Law on Civil Unions in Italy}

Only in 2016 and only after a heated judicial and political struggle, the Parliament passed a law which allowed same-sex civil unions in Italy. Schmitt et al (2013) comparing two Catholic countries as Spain and Italy stated that the Italian difficulties in passing a law were clearly due to the role played by the Catholic Church. Indeed, they noted that: "In Italy, the Catholic Church is a powerful and active societal veto player having direct access to the decision-making process. Its mobilization capacity is very high owing to the geographical proximity of the Vatican and an extremely

\footnotetext{
${ }^{2}$ See also Guiso et al. (2003), who have shown that even though religious beliefs are associated with "good" economic attitudes, for instance, trust in others, religious people on average tend to be more intolerant of diversity than non-religious people.
} 
religious population" (p. 439). In the more secularized Spain, Catholic Church was not able to exert a such high pressure on the political process and therefore a law on same-sex marriage passed about ten years before with respect to Italy (see also Knill and Preidel 2014 for a comparison between Italy and Ireland). Also Marzano and Urbinati (2013) highlighted the strong influence that Catholic Church exerts on Italian politics. They argued that the existence of a religious monopoly in the Country implies that the recognition of the rights for sexual minorities, being in contrast with the dominant religious opinion, will always be devalued. Interestingly, Ozzano (2016) argued that Italy is characterized by two forms of Catholicism: one is directly promoted by the Catholic Church and is oriented towards the support of human rights for ethnic and religious minorities - but, at the same time, it is firmly opposed to civil rights for sexual minorities ( see also Zaccaria 2015 and Zaccaria et al. 2018); the other one is instead advanced by some right-wing political parties (Lega Nord, Fratelli D'Italia) and proposes to defend cultural and religious values against the menace coming from both the "Islamification" of the Italian society and the assault to the traditional family done by LGBT movements. In between these positions, the Centre-Left struggles to conciliate the secular progressivism advanced by some of its exponents with the respect of the stances expressed by Catholic Church.

It must be said that the law approved in 2016 was not the first attempt to regulate civil unions in Italy. Indeed, on 8 February 2007, for the first time in Italian history, a bill regarding the legal rights of stable unmarried cohabitants (including samesex couples) was presented by the centre-left government led by Romano Prodi. This initiative triggered a reaction from the Episcopal Conference of Italy (CEI), which made the following public declaration: "We consider the legalization of the cohabitation between unmarried individuals as ethically unacceptable, this represents a danger at social and educational level. Whatever the intention of those proposing this choice, the effect would inevitably be detrimental to the family. In fact, the uniqueness of the marriage covenant would be removed, which alone justifies the rights which are proper to the spouses and which belong only to them. Moreover, history shows that every law creates mentality and customs. An even more serious problem would be represented by the legalization of unions of people of the same sex, because, in this case, the sexual difference, which is insuperable, would be denied. These reflections do not prejudice the recognition of the dignity of every person; we all confirm our respect and our pastoral concern...[A] Catholic member of the parliament has the moral duty to clearly and publicly express his/her disagreement and to vote against this bill" (Official Note of the Episcopal Conference of Italy, 28 March 2007).

A public manifestation, the so-called "Family Day", was immediately organized in Rome by various Catholic movements and sustained by centre-right political leaders to protest against the legislative initiative. The opposition of the Catholic component inside the same centre-left coalition led to numerous changes to the original bill, leading to an inevitable delay of the discussion in Parliament. In January 2008, the fall of Prodi's government and the entry into office of the new centre-right government implied the definitive abandonment of the bill (see Donà 2009 for a more detailed discussion of the political debate generated by this first attempt to regulate civil unions). 
After years of silence, the debate over the issue was again opened in 2014, when for the first time, the Italian Constitutional Court recognized a marriage in which the groom changed his gender (sentence n.170/2014). This act delegitimized the imposition of divorce (as required by Italian law in these cases), thus inviting the Italian Parliament to intervene on "the detected condition of illegality in the legislation due to the current deficiency of protection of human rights". In the same year, several left-wing municipalities in the country (including Rome, Milan and Naples) started to record same-sex marriages that had been celebrated in other countries in their civil registers.

This initiative triggered the immediate reaction of the centre-right Interior Minister, who ordered local prefects to cancel any such transcriptions. A judicial struggle followed, in which at first the mayors expressed thanks for the 12 February 2015 sentence of the Latium regional administrative court (TAR). However, this decision was appealed by the Interior Minister to the Consiglio di Stato (the supreme Italian administrative court). The Consiglio established, in October 2015, that the marriage of a same-sex couple could not be legally recognized given that the "difference between sexes is an 'ontological' requirement of marriage".

In 2015, the European Court of Human Rights condemned Italy for not recognizing the rights of sexual minorities. Finally, in February 2016, the Senate of the Italian Republic, again ruled by a centre-left majority, started to discuss the approval of a new law on the issue. ${ }^{3}$ Simultaneously, in his address to the officials of the Roman Rota, Pope Francis I declared that: "The Church has indicated to the world that, among other things, there can be no confusion between the family desired by God and any other kind of union [...]. The family, founded upon an indissoluble, unitive and procreative marriage, belongs to the 'dream' of God and that of the Church, for the salvation of humanity". This was probably an attempt to influence the ongoing debate. If so, it did not work (at least not completely), as the Senate approved the law on February 25 and in May 2016, after years of a regulatory vacuum, the law nr. $76 / 2016$ passed also at the Chamber of Deputies.

This law recognized the legal status of same-sex couples through civil unions. However, this law represented a compromise between Catholic conservatism and left-wing progressivism. Namely, that same-sex marriages and opposite-sex marriages are not equal. A very useful synthesis of the various points of view on civil unions can be found in Lasio and Serri (2017). ${ }^{4}$ The law established some rights/ duties similar to those in marriage. These included the obligation to morally and economically sustain each other, the same hereditary rights as married couples, a similar patrimonial regime and the right of leave of absence from work if a partner

\footnotetext{
3 Parliamentary work to draw up a bill had started in June 2014 when the senator Monica Cirinnà filed the first draft. Three drafts were necessary to arrive to the final text presented to the Senate for the final approval. One of the most relevant changes required for the approval has been the elimination of the possibility of step-child adoption for same-sex couples. The approved law is also known as "Cirinnà Law" in honour of its proponent. See Cavaletto (2017) and Danna (2018) for more details on the debate that has led to the approval of the law.

4 See also Breschi et al. (2018) for a discussion of similar solutions adopted in Italy in the case of other religious issues such as abortion, cremation and the use of religious symbols in public schools.
} 
is severely ill. However, there are still several substantial differences from the legal status of heterosexual married couples. Specifically, same-sex couples can neither adopt children (even in the case of step-child adoption, which in the original draft of the bill was consented) nor use medically assisted procreation, reflecting the Catholic Church's stance on procreation. Coherently, Baiocco et al. (2020) analysing the attitude of Italian teachers and educators towards children raised by same-sex parents found that the stronger their religious involvement, the sharper their opposition to same-sex parenting.

Moreover, a period of separation is not required by law before the dissolution of a civil union, as is the case for marriages. The Italian legislature settled on obligatory prior separation as an instrument to give space to save marriages. It must last at least six months, if both spouses decide to get divorced by mutual consent, or twelve months, if there is no agreement between spouses.

Finally, there is no fidelity obligation. This last point could be read as an attempt on the part of the legislature to refuse to recognize the same inviolable bond established for married couples and thereby align itself with the Catholic position. It should also be noted (Cipriani 2017) that the words "family" or "marriage" have been avoided in the legal text, so as to delineate this kind of partnership and one assumes, to avoid offending Catholic sensibility. The reader is referred to Cipriani's work for more details on the different legal statuses of civilly united couples and legally married couples.

\section{Methods and Data}

All the data used in this paper come from Italian civil registers and are collected by the ISTAT for the period 2016-2018. Note that for privacy reason, ISTAT does not publish individual level data but only aggregated statistics on total number of civilly united individuals broken down by gender, age and regions.

However, these data are sufficient to calculate a crude rate of civilly united individuals per 1000 people in each Italian region on 1 January 2019, according to the formula reported in Eq. 1. 5

$$
\text { Civ_united_crude_rate }=\frac{\text { Civilly united resident in region } X}{\text { Total Population resident in region } X} 1000 .
$$

With the aim of analysing the relationship between the diffusion of civil unions and religious secularization, the above depicted crude rate of civilly united individuals

\footnotetext{
5 All the data used in this paper do not come from sampling procedure. They all come from public registers and are publicly available on ISTAT website: https://demo.istat.it/pop2019/index.html.

The total number of civil unions celebrated from June 2016 to December 2017 in Italy is 6,713, while according to data reported by the Italian Ministry of the Interior, there were 2,341 civil unions in 2018. However, this number is provisional, since ISTAT has not yet validated these statistics. Considering the civil unions celebrated in Italy and those transcribed in Italy but celebrated in another country together, 17,341 Italian residents were joined in a civil union on 1 January 2019 (over a population of 60,359,546 inhabitants). See also Pagliacci (2019) for a description of this data source.
} 
was regressed using the OLS technique against the percentage of heterosexual marriages celebrated with the civil rite over the total number of marriages (religious marriages + civil marriages) in each region in 2017 (the latest year available in official statistics). In particular, the following equation was estimated:

$$
\text { Civ_united_crude_rate }{ }_{i}=\alpha+\beta * \text { civil_marriage }{ }_{i}+\varepsilon_{i},
$$

where $i=$ Piedmont, Lombardy,..., Sicily, civil_marraige ${ }_{i}$ is the percentage of civil marriages celebrated in region $i$ and $\varepsilon$ is the error term.

It is worthwhile to remark again that these data come from official source and are not the results of sampling procedure.

It should be noted that Impicciatore and Billari (2012) also used the choice between religious and civil rates as an indicator of religious secularization, arguing that: “...[E]specially in Italy, where religious marriages are still predominant, a civil marriage clearly represents a secularized choice, displayed to the outside world" (p. 121).

A high percentage of heterosexual couples opting for a civil celebration should be indicative of a weaker influence of religion in people's choices. Having few observations, including other explicative variables, is problematic, since this will consume a degree of freedom.

However, to avoid possible criticism regarding relevant omitted variables and/ or endogeneity, the instrumental variables (IVs) approach was also implemented. This approach is well known in econometric literature and consists of finding one or more variables that are correlated with the possible endogenous regressor, but not directly with the dependent variable (the so-called exclusion restriction). In other words, the IV approach identifies the effect of a regressor suspected of being endogenous (the IV) by using one or more variables (the instruments) for which the effect on the dependent variable is not direct, but occurs only through the relationship with the IV. The interested reader is referred to Angrist and Pischke (2009) for technical details on this technique. Two candidates for IVs are the crude divorce rate registered in 1980 and the 1979 percentages of votes obtained by the Italian Communist Party (PCI).

Since Catholics believe in the indissolubility of religious marriage, a high percentage of divorce should be a marker of a more secularized society. The divorce rate is usually employed in the literature dealing with the "Second Demographic Transition" theory, as one of the main empirical indicators of the shift from the influence of normative authorities, such as the Catholic Church, in each aspect of private life to individual freedom that occurred in the second half of the twentieth century in Northern America and Western Europe (see for instance Lesthaeghe 2014). Recently, also De la Croix et al. (2019) argued that the legalization of divorce in Italy played a central role in unleashing the forces of secularization.

A time lag of about 40 years is used since it can in no way be claimed that the current civil union rate is caused by the divorce rate 40 years prior. However, if a higher divorce rate reflects a weaker adherence to Catholic beliefs, it seems reasonable to assume that regions that were less prone to obey to Catholic precepts in the 1980s are still more secularized forty years after. It is useful to note that divorce was 
introduced into Italian law only in 1970. The use of data relative to the very first years after the introduction of the divorce law has been avoided, since the law was subject to an abrogative referendum in 1974 (in which Italians voted for the law to remain in force). Another reason to use this lagged measure is that more than $90 \%$ of marriages were still celebrated according to religious rites in the early 1980s (see Ruiu and Breschi 2015).

The choice of also using the percentage of votes going to the PCI as an IV is due to its tense relationship with the Catholic Church. For instance, the PCI was one of the main promoters of the Italian law on divorce. The position of the Italian Catholic Church regarding voting for the communist party was clearly expressed by a note of the Episcopal Conference of Italy (CEI) in December 1975: "It is incompatible with the profession of the Christian faith to adhere to or support those movements, even if in diverse forms, which are based on Marxism and which in our country have their fullest expression in Communism". The same Pope Paulus VI in May 1976 expressed his concerns for the PCI candidature of several Catholic believers, saying that being an adherent to the Catholic faith "cannot be put together with a view totally and intrinsically opposed to its nature". Therefore, a higher percentage of votes for the PCI should be indicative of a weaker influence of the Catholic Church in the choices people make. The choice of using two IVs instead of a unique instrument allows the above depicted exclusion restrictions to be tested using the Sargan-Hansen test.

Also the data for the regional crude divorce rates are from ISTAT, while the share of votes obtained by the PCI are from the historical archive of the Italian Ministry of the Interior. ${ }^{6}$.

\section{Results}

Figure 1a-c reports the crude rates calculated according to Eq. 1 by means of a thematic map. Obviously, when men/women are considered, the crude rate denominator is, respectively, the male/female population. Note also the data about the resident population are from official Italian statistics produced by ISTAT.

The regional difference in the percentage of marriages celebrated with the civil rite in 2017; the 1980 crude divorce rates and the 1979 percentages of the vote given to the PCI are presented in Fig. $2 \mathrm{a}-\mathrm{c}$.

In Table 2, the results of the above-mentioned linear regression are reported. The dependent variable is the crude rate of civilly united individuals, including both male and female same-sex couples (column 1), or alternatively same-sex male unions and same-sex female unions are considered (columns 2 and 3, respectively). Finally, also the results obtained using the IV approach instead of OLS are reported (column 4).

\footnotetext{
6 These data are publicly available on the official website of the Italian Ministry of the Interior: https:// elezionistorico.interno.gov.it/
} 
A- Civilly united individuals per 1,000 people

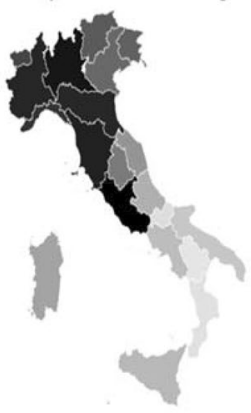

B- Gay men civilly united per 1,000 male population

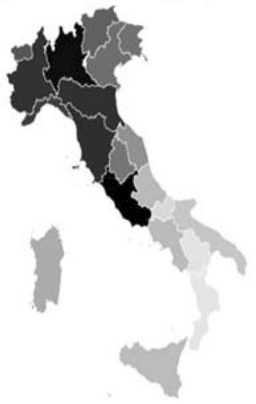

C-Lesbian women civ. united per 1,000 female population
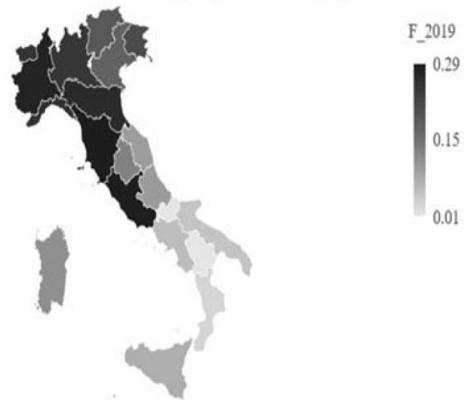

Fig. 1 Civilly united individuals per 1,000 people, 2016-2018. Source https://demo.istat.it/pop2019/ index.html

\section{Discussion}

According to Fig. 1, Northern regions have the highest rates of civilly united individuals in terms of the total population. When gender is considered, civil unions seem to be more prevalent among same-sex male couples than among female couples. In addition, civilly united people tend to be fairly older than married people; indeed the average age of civilly united gay men/lesbian women was 49.7/44.9 against 37.9/33.7 among newly married heterosexual men/women in 2017 (our calculation from raw data not reported in Fig. 1).

Note also that a similar North-South gradient in the diffusion of civil marriages seems to characterize Italy (Fig. 2a). Also the share of votes for the PCI and divorce rates were higher in the Northern part of the Country and in Central Italy (Fig. 2b, c) than in Southern Italy. This seems to be coherent with the idea, proposed in the methods section of this work, that these parts of the Country were more secularized already forty years ago.

Finally considering Table 2, nearly $79 \%$ of the variability in the crude rate of civilly united individuals is explained by the linear relationship with the civil marriage rate in a given area. The direction of the relationship is positive, as expected, and the estimates indicate that an increase of one percentage point in 
A - Marriages celebrated with civil rite, 2017
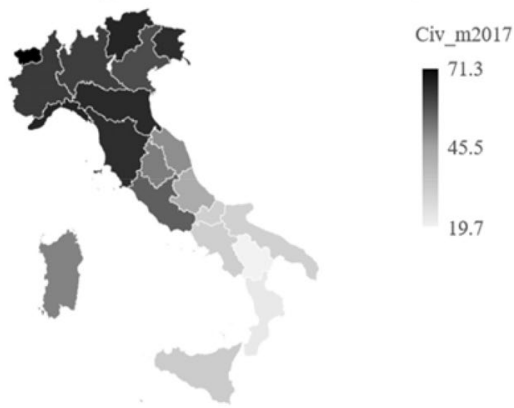

C - Crude divorce rate, 1980

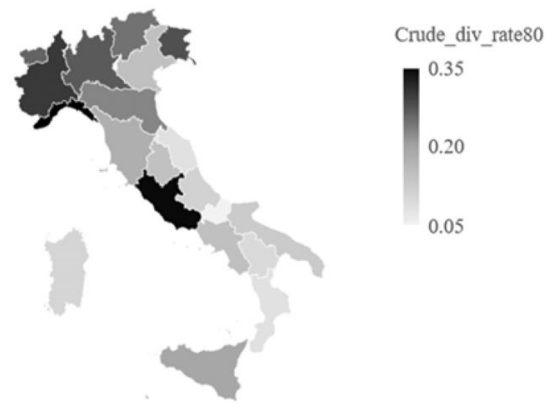

B - $\%$ of votes to the PCI, 1979

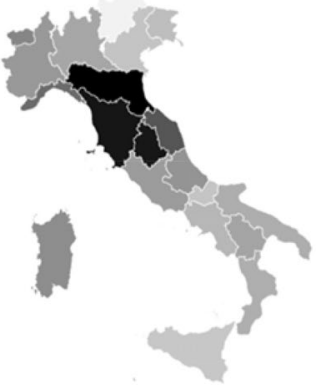

$\%$ PCI79

47.33

29.21

11.09

Fig. 2 The \% of Heterosexual marriages celebrated with the civil rite in 2017, regional crude divorce rate and percentage of vote going to PCI, 1979-80. Source Data on marriage and on divorce derived from https://dati.istat.it/; Data on the 1979 elections are from

Table 2 Civil unions and secularization

\begin{tabular}{lllll}
\hline & $(1)$ OLS $(\mathrm{M}+\mathrm{F})$ & $(2)$ OLS $(\mathrm{M})$ & (3) OLS (F) & (4) IV (M+F) \\
\hline Civil marriage & $0.008^{* * *}$ & $0.010^{* * *}$ & $0.005^{* * *}$ & $0.011^{* * *}$ \\
& $(0.001)$ & $(0.001)$ & $(0.000)$ & $(0.001)$ \\
\multirow{2}{*}{ cons } & $-0.152^{* * *}$ & $-0.185^{* * *}$ & $-0.122^{* * *}$ & $-0.287 * * *$ \\
& $(0.027)$ & $(0.037)$ & $(0.020)$ & $(0.071)$ \\
$\mathrm{N}$ & 20 & 20 & 20 & 20 \\
$\mathrm{R} 2$ & 0.788 & 0.742 & 0.829 & 0.688
\end{tabular}

Under-identification test (Kleibergen-Paap rk LM statistic): $10.461 \chi^{2} P$-val $=0.0053$

Weak instrument robust tests and confidence sets for linear IV

CLR I stat $=10.55 P$. val $=0.0041 ; 95 \%$ Confidence Interval for $\beta$ [0.008011, 0.015559]

Over-identification test of all instruments $0.1291 P$-val $=0.7193$

Heteroskedasticity robust standard errors in parentheses

$* P<0.10, * * P<0.05, * * * P<0.01$ 
the civil marriage rate leads to an increase of 0,008 in the crude rate of civilly united individuals. To better understand the relevance of this impact, consider that Lombardy has a civil marriage rate that is equal to 62.1, while in Calabria the same rate is 22.5 (see Fig. 2a); the estimated coefficient in column 1 implies that it could expected a difference of about 0.30 in the crude rate of civilly united individuals between the two regions. The effect is stronger among men than among women. Griffith and Hebl (2002) found that self-acceptance of sexual identity is easier for lesbians than for gay men. A possible explanation then for the latter result may be that it is easier for men to officialize their union in more secularized regions, and this magnifies the coefficient associated with our proxy of religious secularization for men.

Accordingly, Piumatti (2017) showed that the existence of gender role beliefs may further exacerbate the link between religiosity and negative attitude towards LGBT people (see also Santona and Tognasso 2018).

In addition, using an Italian sample of 120 lesbian women and 170 gay men, Scandurra et al. (2019) reported that gay men tend to feel social stigma more than lesbian women, while the latter are also more willing to become parents. The latter evidence may also in part explain why civil unions are less diffused among women than men. In Italy, access to artificial insemination is permitted only for heterosexual couples, while surrogacy is forbidden. Hence, same-sex couples who desire to become parents are forced to travel to a foreign country which allows these practices. However, once they return to Italy, the civil official may refuse the transcription of the birth, since Italian law does not explicitly provide dispositions about these situations. If this is the case, a long and expensive judicial battle is needed to obtain the transcription. Accordingly, Franchi and Selmi (2020) reported that this was a serious concern for the lesbian couples that they interviewed. As such, given that joining in a civil union does not entitle same-sex couples to access to parenthood, this choice may hold less appeal for lesbian women whose desire to become parents is higher than that of gay men. Furthermore, Barbagli (2018) argued that in Scandinavian countries, unions between lesbian women have reached the same number as unions between gay men only when these countries have approved a law allowing child adoption. Kolk and Andersson (2020) proposed a similar explanation for the initial larger diffusion of same-sex marriage among gay men observed in Sweden after the introduction of the civil union law.

When the IV estimates are considered, the previous reported results are confirmed (the estimated coefficient associated with civil marriage is even higher). Note that at the end of the table, the under-identification test strongly rejects the null hypothesis of the absence of a correlation between the instruments and the IVs.

According to the results of the conditional likelihood ratio (CLR) test, it is also possible to exclude the possibility that the inference produced in the estimates is affected by the problem of weak instruments, i.e. a weak correlation between instrumented variable and IVs. The presence of weak instruments could make the IV estimates even more distorted than OLS estimates, in addition to generating misleading estimates of statistical significance even with a very large sample size.

Finally, under the null hypothesis of the over-identification test (also known as Sargan-Hansen test), all the instruments are uncorrelated with the error term and 
were correctly excluded from the estimated Eq. 2. It is not possible to reject the null, and hence this test also supports the validity of the proposed instruments.

\section{Conclusions}

The legal recognition of civil unions between same-sex partners in May 2016 could be defined as a revolution in the system of legal norms regarding the "heterosexual family-centric-system" in Italy. If one accepts the idea that the percentage of LGBT people should be more or less the same across the country, then it is possible to speculate that the higher the number of same-sex couples deciding to join in a civil union, the lower the social barriers to officialize a relationship.

One of the main barriers to the same approval of the law on civil unions has been the strong influence the Catholic Church has always exerted on Italian society (Schmitt et al. 2013; Wertman 1982). However, Italy seems to be characterized by a high degree of heterogeneity in terms of religious secularization (Breschi et al. 2018). This interpretation seems to be confirmed by our empirical results. When an indicator of secularization (the percentage of marriages celebrated with the civil rite) is used as an explicative variable in a linear regression in which the 2016 to 2018 regional crude civil union rate is explicated, the relation is positive and highly statistically significant (even when an IV approach is implemented). The regions that are more secular are also characterized by a wider diffusion of civil unions.

Studying this topic in Italy is particularly interesting, since the country has been defined as the least secularized among economically developed nations (see Breschi et al. 2018 for a brief discussion). The obtained results confirm this view at least for Southern Italy. The moral pressure that the Church is still able to exert in Southern Italy has been proposed as the main explanation of the low diffusion of civil unions in this area of the Italy. From a practical point of view, these findings suggest that sexual minority people should be helped to cope with the psychological stress deriving from the social stigma attached to the officialization of their unions (see also Bertone and Franchi 2014); otherwise, their civil rights will remain only on the paper, at least in a relevant part of the Italian Country.

One of the limits of this work is that given the scant availability of data it is possible to know only where civilly united couples are currently residents, but not where they were born. Hence, it is possible that LGBT individuals migrated from Southern to Northern Italy to live in a less discriminatory region (see Pagliacci 2019 for a discussion). Even if this were the case, it should be said that this would still reflect the difficulty of accepting sexual minorities in less secularized regions.

Another issue raised in the paper and on which it is worthwhile to devote more attention in the future is the higher tendency to celebrate a civil union among gay men than among lesbian women. Following Barbagli (2018), it has been surmised that since lesbian women seem to give more importance on becoming parents with respect to gay men, the fact that, according to the Italian law, a civilly united samesex couple is not entitled to adopt children or to use artificial insemination has eventually reduced the incentives of celebrating unions among women. If this hypothesis 
will be confirmed, this could offer insights for increasing the officialization of civil unions also among women.

Finally, this work should be interpreted as a first explorative analysis and as such it has raised more questions than those it was possible to answer. To better understand the mechanisms hidden behind the difficulty of celebrating same-sex civil unions in Southern Italy, individual survey data on individual motivations would be needed. Nevertheless, it should be noted that the same barriers that may obstacle the choice of joining a civil union may also inhibit the participation to a survey on this topic. Hence, even this latter aspect represents a challenge from a methodological point of view.

Funding Open access funding provided by Università degli Studi di Sassari within the CRUI-CARE Agreement. The research activity carried out by Gabriele Ruiu is in part financed by the "Fondo per il finanziamento dei dipartimenti universitari di eccellenza" (law 232/2016). Gabriele Ruiu recognizes also the financial support of the Jack Shand Research Grant Program promoted by the Society for the Scientific Study of Religion.

Data availability Data are available upon request to the corresponding author.

\section{Compliance with ethical standards}

Conflict of interest The authors declare that they have no conflict of interest.

Open Access This article is licensed under a Creative Commons Attribution 4.0 International License, which permits use, sharing, adaptation, distribution and reproduction in any medium or format, as long as you give appropriate credit to the original author(s) and the source, provide a link to the Creative Commons licence, and indicate if changes were made. The images or other third party material in this article are included in the article's Creative Commons licence, unless indicated otherwise in a credit line to the material. If material is not included in the article's Creative Commons licence and your intended use is not permitted by statutory regulation or exceeds the permitted use, you will need to obtain permission directly from the copyright holder. To view a copy of this licence, visit http://creativecommons.org/ licenses/by/4.0/.

\section{References}

Anderton, C. L., Pender, D. A., \& Asner-Self, K. K. (2011). A review of the religious identity/sexual orientation identity conflict literature: Revisiting Festinger's cognitive dissonance theory. LGBT Issues in Counseling, 5(3-4), 259-281.

Angrist, J. D., \& Pischke, J. S. (2009). Mostly harmless econometrics. Princeton, NJ: Princeton University Press.

Baiocco, R., Fontanesi, L., Santamaria, F., Ioverno, S., Marasco, B., Baumgartner, E., et al. (2015). Negative parental responses to coming out and family functioning in a sample of lesbian and gay young adults. Journal of Child and Family Studies, 24(5), 1490-1500.

Baiocco, R., Rosati, F., Pistella, J., Salvati, M., Carone, N., Ioverno, S., et al. (2020). Attitudes and beliefs of Italian educators and teachers regarding children raised by same-sex parents. Sexuality Research and Social Policy. https://doi.org/10.1007/s13178-019-00386-0.

Barbagli, M. (2018, May 18). Gender Gap anche tra lesbiche e gay. Lavoce.info. Retrieved August 20, 2018, from https://www.lavoce.info/archives/53134/gender-gap-anche-tra-lesbiche-e-gay. 
Bengtsson, N. (2019). Are religions for sale? Evidence from the Swedish Church revolt over same-sex marriage. Journal for the Scientific Study of Religion, 58(2), 336-359.

Berggren, N., Bjørnskov, C., \& Nilsson, T. (2017). What aspects of society matter for the quality of life of a minority? Global Evidence from the new gay happiness index. Social Indicators Research, 132, 1163-1192.

Bertone, C., \& Franchi, M. (2014). Suffering as the path to acceptance: Parents of gay and lesbian young people negotiating Catholicism in Italy. Journal of GLBT Family Studies, 10(1-2), 58-78.

Boertien, D., \& Vignoli, D. (2019). Legalizing same-sex marriage matters for the subjective well-being of individuals in same-sex unions. Demography, 56(6), 2109-2121.

Breschi, M., \& Ruiu, G. (2016). Superstitions, religiosity and secularization: An analysis of the periodic oscillations of weddings in Italy. Genus Journal of Population Sciences. https://doi.org/10.1186/ s41118-016-0012-0.

Breschi, M., Ruiu, G., \& Francini, M. (2018). "Ashes to Ashes...": Could the recent evolution of the cremation practice in italy be interpreted as an indication of secularisation? Review of Religious Research, 60(4), 519-533.

Cavaletto, G. M. (2017). Civil unions in Italy. Italian Politics, 31(1), 194-210.

Cipriani, N. (2017). Unioni Civili: Same-sex partnerships law in Italy. The Italian Law Journal, 3(2), $343-355$.

Danna, D. (2018). The Italian debate on civil unions and same-sex parenthood: The disappearance of lesbians, lesbian mothers, and mothers. Italian Sociological Review, 8(2), 285-308.

De la Croix, D., Mariani, F., \& Mercier, M. (2019). Driven by institutions, shaped by culture: Human capital and the secularization of marriage in Italy. Université catholique de Louvain. Retrieved June 18, 2020, from https://sites.uclouvain.be/econ/DP/IRES/2019022.pdf.

Donà, A. (2009). From Pacs to Didore: Why are civil partnerships such a divisive issue in Italian politics? Bulletin of Italian Politics, 1(2), 333-346.

Ellison, C. G., Acevedo, G. A., \& Ramos-Wada, A. I. (2011). Religion and attitudes toward same-sex marriage among U.S. Latinos. Social Science Quarterly, 92(1), 35-56.

Gay, D. A., Lynxwiler, J. P., \& Smith, P. (2015). Religiosity, spirituality, and attitudes toward same-sex marriage: A cross-sectional cohort comparison. Sage Open. https://doi.org/10.1177/2158244015 602520 .

Franchi, M., \& Selmi, G. (2020). Same-Sex Parents Negotiating the Law in Italy: Between Claims of Recognition and Practices of Exclusion. In M. Digoix (Ed.), Same-Sex Families and Legal Recognition in Europe (pp. 73-93). Cham (Che): Springer.

Griffith, K. H., \& Hebl, M. R. (2002). The Disclosure dilemma for gay men and lesbians: "Coming Out" at work. Journal of Applied Psychology, 87(6), 1191-1199.

Guiso, L., Sapienza, P., \& Zingales, L. (2003). People's opium? Religion and economic attitudes. Journal of Monetary Economics, 50(1), 225-282.

Impicciatore, R., \& Billari, F. C. (2012). Secularization, Union formation practices, and marital stability: Evidence from Italy. European Journal of Population, 28, 119-138.

Jäckle, S., \& Wenzelburger, G. (2015). Religion, religiosity, and the attitudes toward homosexuality: A multilevel analysis of 79 countries. Journal of Homosexuality, 62(2), 207-241.

Janssen, D. J., \& Scheepers, P. (2018). How religiosity shapes rejection of homosexuality across the globe. Journal of Homosexuality. https://doi.org/10.1080/00918369.2018.1522809.

Jennings, N. (2011). Same-sex marriage on the Iberian Peninsula: The Church and Franco's competing legacies. Claremont-UC Undergraduate Research Conference on the European Union. https://doi. org/10.5642/urceu.201101.06.

Kolk, M., \& Andersson, G. (2020). Two decades of same-sex marriage in Sweden: A demographic account of developments in marriage, childbearing, and divorce. Demography. https://doi. org/10.1007/s13524-019-00847-6.

Knill, C., \& Preidel, C. (2014). Institutional opportunity structures and the Catholic Church: Explaining variation in the regulation of same-sex partnerships in Ireland and Italy. Journal of European Public Policy. https://doi.org/10.1080/13501763.2014.951066.

Lasio, D., \& Serri, F. (2017). The Italian public debate on same-sex civil unions and gay and lesbian parenting. Sexualities. https://doi.org/10.1177/1363460717713386.

Lesthaeghe, R. (2014). The second demographic transition: A concise overview of its development. Proceedings of the National Academy of Sciences of the United States of America. https://doi. org/10.1073/pnas.1420441111. 
Lingiardi, V., Nardelli, N., Ioverno, S., Falanga, S., Di Chiacchio, C., et al. (2016). Homonegativity in Italy: Cultural issues, personality characteristics, and demographic correlates with negative attitudes toward lesbians and gay men. Sexuality Research and Social Policy, 13(2), 95-108.

Marzano, M., \& Urbinati, N. (2013). Missione impossibile: la riconquista cattolica della sfera pubblica. Bologna: Il Mulino.

Ozzano, L. (2015). The debate about same-sex marriages/civil unions in Italy's 2006 and 2013 electoral campaigns. Contemporary Italian Politics, 7(2), 144-160.

Ozzano, L. (2016). Two forms of Catholicism in twenty-first-century Italian public debate: An analysis of positions on same-sex marriage and Muslim dress codes. Journal of Modern Italian Studies, 21(3), 464-484.

Page, M. J. L., Lindahl, K. M., \& Malik, N. M. (2013). The role of religion and stress in sexual identity and mental health among lesbian, gay, and bisexual youth. Journal of Research on Adolescence, 23(4), 665-677.

Pagliacci, F. (2019). Friendly neighbours! The role of community-level drivers in the territorial distribution of same-sex couples in Italy. Papers in Regional Science. https://doi.org/10.1111/pirs.12447.

Pecheny, M., Jones, D., \& Ariza, L. (2011). Sexual Politics and Religious Actors in Argentina. Religion \& Gender, 6(2), 205-225.

Perry, S. L. (2015). Bible beliefs, conservative religious identity, and same-sex marriage support: Examining main and moderating effects. Journal for the Scientific Study of Religion, 54(4), 792-813.

Pew Research Center. (2013). The global divide on homosexuality. Greater acceptance in more secular and affluent countries. Washington, DC: Pew Research Center.

Piumatti, G. (2017). A mediational model explaining the connection between religiosity and anti-homosexual attitudes in Italy: The effects of male role endorsement and homosexual stereotyping. Journal of Homosexuality, 64(14), 1961-1977.

Powdthavee, N., \& Wooden, M. (2014). Life satisfaction and sexual minorities: Evidence from Australia and the United Kingdom. Journal of Economic Behavior \& Organization, 116, 107-126.

Rollè, L., Chinaglia, L., Curti, L., Magliano, A., Trombetta, T., et al. (2018). Attitudes of Italian group toward homosexuality and same-sex parenting. Journal of Psychology and Psychotherapy Research, $5,10-25$.

Ruiu, G., \& Breschi, M. (2015). For the times they are a changin': The respect for religious precepts through the analysis of the seasonality of marriages. Italy 1862-2012. Demographic Research, 33(7), 179-210.

Santona, A., \& Tognasso, G. (2018). Attitudes toward homosexuality in adolescence: An Italian study. Journal of Homosexuality, 65(3), 361-378.

Saporiti, M. (2017). Public officers and same-sex civil unions in Italy: An unsolved principled question?. Oxford Journal of Law and Religion, 6, 604-609.

Scandurra, C., Bacchini, D., Esposito, C., Bochicchio, V., Valerio, P., \& Amodeo, A. L. (2019). The influence of minority stress, gender, and legalization of civil unions on parenting desire and intention in lesbian women and gay men: Implications for social policy and clinical practice. Journal of GLBT Family Studies, 15(1), 76-100.

Schmitt, S., Euchner, E. M., \& Preidel, C. (2013). Regulating prostitution and same-sex marriage in Italy and Spain: the interplay of political and societal veto players in two catholic societies. Journal of European Public Policy, 20(3), 425-441.

Sherkat, D. E., Powell-Williams, M., Maddox, G., \& de Vries, K. M. (2011). Religion, politics, and support for same-sex marriage in the United States, 1988-2008. Social Science Research, 40(1), $167-180$.

Vignoli, D., \& Salvini, S. (2014). Religion and union formation in Italy: Catholic precepts, social pressure, and tradition. Demographic Research, 31(35), 1079-1106.

Walther, C. S., Poston, D. L., \& Gu, Y. (2011). Ecological analyses of gay male and lesbian partnering in the metropolitan United States in 2000. Population Research and Policy Review, 30, 419-448.

Wertman, D. A. (1982). The catholic church and Italian politics: The impact of secularization. West European Politics, 5(2), 87-107.

Worthington, R. L. (2004). Sexual identity, sexual orientation, religious identity, and change: Is it possible to depolarize the debate? The Counseling Psychologist, 32(5), 741-749.

Zaccaria, F. (2015). Catholic Church, Young People, and Human Rights in Italy. In H. G. Ziebertz \& G. Črpić (Eds.), Religion and Human Rights (pp. 93-102). Cham (Che): Springer. 
Zaccaria, F., Anthony, F. V., \& Sterkens, C. (2018). Religion and Civil Rights in Italy: An Empirical Exploration Among Secondary School Students. In H. G. Ziebertz \& C. Sterkens (Eds.), Religion and Civil Human Rights in Empirical Perspective (pp. 91-119). Cham (Che): Springer.

Zmyj, N., \& Huber-Bach, L. (2019). German adolescents' homonegativity and the relationship to their religious denomination and gender role orientation. Journal of LGBT Youth. https://doi. org/10.1080/19361653.2019.1641174.

Publisher's Note Springer Nature remains neutral with regard to jurisdictional claims in published maps and institutional affiliations. 